\title{
Psychopathology and Depression in the Middle East
}

\author{
Kemal Sayar ${ }^{1}$, Samet Kose ${ }^{2,3}$
}

ÖZET:

Ortadog̃u'da psikopatoloji ve depresyon

Batı Dünyası'nın bakış açısılla şekillenmiş günümüz psikoterapi yöntemleri, sosyal ve kültürel farklılıkları yeteri kadar işaret edemeyebilir. Oysaki sosyal ve kültürel farklılıklar Batı toplumları dışındaki topluluklarda yaşam normlarının daha farklı belirlenmesine neden olmaktadır. Ortadog̃u toplumlarında kişinin ruh sag̃liğı ve bozuklug̃u, bu sebeple Batı toplumlarındaki gibi deg̃erlendirilmez. Bu durum Ortadog̃u toplumlarında Batı toplumlarından farklı psikopatolojilerin görülmesine neden olur. Bu șartlar altında psikoterapi yöntemlerinin de sosyal ve kültürel bir elekten geçirilmesi zorunludur. Yazarlar ayrıca günümüzde acı çekmenin medikalizasyonu, hastalık kategorilerinin nesneleștirilmesi ve varoluşun ahlaki anlamın kaybetmesinin etkilerini tartışmaktadırlar.

Anahtar sözcükler: psikopatoloji, depresyon, psikoterapi, modernizasyon, hüzün

Journal of Mood Disorders 2012;2(1):21-7

\begin{abstract}
:
Psychopathology and depression in the Middle East

Psychotherapy methods are mostly constructed by the Western societies and thus they might fail to address the social and cultural differences of other, non-Western societies. Different social and cultural factors account for the development of different norms in non-Western countries. Psychiatrists should take into account that there are different signs of psychological wellness and psychopathology in non-Western societies. Such social and cultural differences are considered to be underlying factors of different forms of psychopathologies that are predominantly observed in clinical settings among the Middle Eastern patients. Therefore, psychiatrists should consider administering the most appropriate therapeutic techniques based on such social and cultural differences. Authors also discuss the impact of medicalization of human suffering, reification of illness categories, and loss of moral meaning of being.
\end{abstract}

Key words: psychopathology, depression, psychotherapy, modernization, sadness

Journal of Mood Disorders 2012;2(1):21-7
${ }^{1} \mathrm{MD}$, Marmara University, Deparment of Psychiatry, Istanbul - Turkey ${ }^{2,3} \mathrm{MD}$, PhD Vanderbilt University, Department of Psychiatry, Nashville, TN, US; University of Mississippi, Department of Psychiatry and Human Behavior, Jackson, MS, US

Yazıșma Adresi / Address reprint requests to: Kemal Sayar, MD, Marmara University, Deparment of Psychiatry, Istanbul-Turkey

Elektronik posta adresi / E-mail address: kemalsayar@gmail.com

Kabul tarihi / Date of acceptance: 17 Aralık 2011 / December 17, 201

Bag̃ıntı beyanı:

K.S. S.K. Yazarlar bu makale ile ilgili olarak herhangi bir cıkar catısması bildirmemislerdir.

Decloration of interest:

K.S., S.K.: The authors declare that they have no conflict of interests regarding the conten of this article.

\section{The Middle East: Characteristic Features}

The Middle East is a vast area of ancient civilizations, rich in history and heritage. Its major cities are vibrant places where tradition, customs, faith, and values meet with modern lifestyles and diverse societies and worldviews. Religious identity is an important ingredient in the fabric of the Middle Eastern societies (1).

The Middle East is 'where bombs from the Western world drop down' as portrayed by the Turkish writer Nihat Genç. This is an imaginary geography implying an area extending from Libya to Afghanistan; including the countries of South-West Asia and North Africa. This area includes many civilizations and cultures that have both similarities and differences with each other. Jordan, Lebanon, Saudi Arabia, Sudan, Syria, and the North
African countries like Egypt, Libya, Morocco, Algeria and Tunisia are all located in this region. This region also encloses Northern India, Pakistan, Afghanistan, Iran and Iraq in the East, including even some parts of Central Asia and Turkey.

The Middle East is the cradle of the Judaism, Christianity, and Islam. Islam is part of region's common identity, $90 \%$ of the people in the countries of the region believe in Islam. Religions enable the interaction between local cultures and countries. Edward Said's Orientalism details the extent to which the West's knowledge of Middle Eastern societies was created in the service of either conquering and administering them as colonies or imagining them as exotic lands of freedoms and excesses prohibited in Europe (2). The Orientalists sought to penetrate the 'Arab mind and character' and what they 
found was unsurprisingly, a negative mirror image of the rational, industrious, self-controlled European mind. On the other hand, Thierry Hentsch (3) rejects the use of the term "Middle East" as being an example of so called West's ethnocentric evaluation of the Arab World, Turkey, Iran and parts of Northern Africa. It is only "East" compared to self-proclaimed western position and it is qualified as "Middle" East because it is closer to West than the Far East--lands such as China and beyond. Bearing this ethnocentric bias in mind, we must say that the first psychiatric hospitals of the world were probably built in the Middle East : Baghdad in 705, Cairo in 800, and Damascus in 1270. In Turkey, special psychiatric wards were built onto a general hospital in 1555 and a specific psychiatric hospital was built in 1583. Records show that humane treatments including music therapy, aromatherapy, and bathing were used in these hospitals. Community involved in the applications and procedures for the welfare of the patients (4). Some rural villages were concerned with the rehabilitation and therapy of mentally ill in Anatolia during the Seljukian era and these villages were not taxed (5). The Fool for Love has been an idolatric person for madness, and Majzoob/ who is the person inflicted by love of God has been both a mad and a respected person, blurring the lines of mental well being and illness. Majzoob may be close to God yet his secrets might not be revealed to ordinary people, so diagnosing him as a mentally ill person is problematic in a society where Divine still rules.

"At least do no harm" aptly describes the Ottoman reaction to medicine. Ottomans accepted as unavoidable that sometimes physicians and medicine would harm patients (despite the dictum), or at least not be able to offer any real or concrete comfort. The realistic attitude attests that in the Ottoman case, although a negative association of medicine did exist, it seems to be not the prevalent one; at the same time people did not incline to the other extreme, that of naïve expectation. Illness and death were regarded with acceptance. Early modern Ottomans lived with them as everyday and normal occurrences. Illness could be regarded also as an opportunity. Ottomans were not shy about notifying authorities about other people's impeding death and their wishes to take their place. In Ottoman society as elsewhere, sickness and death were unfortunate events, but they could open new possibilities for others (6).

\section{Mental Health Services in the Middle East}

Despite the glorious past of mental health services in the Middle East, one can say that situation is especially worse in war-torn areas. Mental health and conflicts in the region are escalating. Especially in places like Lebanon, there is a clear link between exposure to war and major depression (7). There is a significant doseresponse relationship between the number of trauma and anxiety, mood and impulse control disorders (8). Especially there is an outbreak of PTSD and depression as well as problems in the family functioning and social exclusion in Palestine, since the Intifada (9). According to El-Sarraj (10), during Israeli rule levels of antisocial behavior and aggression, including homicide, have increased within the Palestinian population. In addition, drug misuse has spread among younger Palestinians (11). Unfortunately, the war takes toll on the mental health services of Iraq. Iraq's largest psychological hospital which had more than 1,500 beds - was destroyed in the war. The staff and patients have left because there was no food or medicine, and female patients in particular were subjected to rape. Children in particular are showing behavioral problems and depression at a higher rate than one would expect in a population this size - three times as high in Iraq (12). The situation is not better in the Palestine either. After the first Intifada, nearly half of the population was suffering from a range of mental health disorders (13). Severe and complex problems could not be resolved with debriefing techniques (13). Many people in the troubled areas of the Middle East have suffered and continue to suffer all types of losses, which often result in chronic cases of unresolved grief and complicated bereavement. Past and present losses are compounded by the apprehension of the 'unknown' and the anticipation of certain future losses, causing a phenomenon known as anticipatory grief (1).

\section{Understanding Mental Health and Sickness in the Middle East}

The description of mental health and sickness in the region is important to understand. Psychiatry is a modernist project and there is a boundary between the normal and the sick. Traditionally in the Middle East, the difference between a person who is deli (insane) and a veli 
(saint) has long posed a problem (14). There is also a difference between collectivistic and individualistic lifestyles. People in the area are taught to adjust to a relationship while repressing internal desires to facilitate interpersonal harmony and unity. That's why people feel a socially diffused responsibility where the feelings of guilt are rare among psychiatric patients. Self-disclosure is not valued by the society. There is restraint and control on feelings. Lowness, humility and modesty are favored over self-serviance and self-focusing. Also spiritual experience of faith reflects and influences cultural ideals in the everyday production of well-being. However, focus of meaning of the Western psychiatry resides in a more secular realm. In the West, the focus of meaning shifts towards individual psychology, meaning that the success of human life lies in the psychological well-being (15). If you are feeling well and happy, this is a sign that proves your life to be a successful one. As signs of happiness might differ, signs of distress might also be different in the Middle Eastern societies. Idioms of distress vary across cultures and the Middle Eastern societies have their own ways of expressing distress. Many Middle Eastern societies localize distress in the heart as opposed to head and mind. They describe emotions in a metaphorical way. There are rich, poetic cultural resources in the form of imagery and language in describing mental health difficulties. For example, Kashmiri women tell that their hearth's burden would lessen or their hearth's pain would reduce (16), while there are some other statements in different areas including Turkey, Iran, Pakistan and Arabian Peninsula such like "my heart is worried", "my heart is anxious", "my heart is wounded", "my heart aches", "my soul is trembling", "heart worry", "chest tightness", "ring around the chest", and the "distress of heart" (17-21). "Medicine for the heart" is a Moroccan way of describing the power of the Quran to heal the heart, an organ and symbol that links spiritual, emotional and physical experience. The recitation of Quranic verses offers housewives living in South Eastern Saharan Morocco a way to manage emotions that distress the heart and body (22).

Punjabi women participating in a focus group in London (23) recognized the English word 'depression', but the older ones used terms such as 'weight on my heart/ mind', or 'pressure on the mind'. Throughout the MiddleEast, references to the heart are commonly understood not just as potential signs of illness but as natural metaphors for a range of emotions (24). Additionally the meaning of sadness is somehow different than its meaning in the West. In Farsi, sadness is associated with personal depth, a sad person is considered as being a thoughtful person (motafakker) where the ability to express sadness in a socially appropriate way is a mark of social competence (17).

\section{Predominance of Specific Psychopathologies in the Middle East}

There are some common characteristics of mental patients in the Middle East. Somatization of psychological problems is common in the region. Each culture has its own emotional lexicon that encodes socially and morally significant values and its own idioms of distress - cultural ways of talking about distress. With globalization, it is likely that these metaphors will change and different idioms of distress will be used. Furthermore, it is possible that an increase in medicalization of depressive symptoms may be seen (25). There is also an important role of the traditional healers. There is reliance upon a deity and religious leaders as a means of coping with mental health issues. Shame and honor are important concepts in the Middle East (22). Ethnographies from nearly all Middle Eastern cultures suggest that the region is characterized by two predominant value systems and their associated etiquettes and self-care practices: that of 'honor-and-modesty' and that of Islam. Psychologically, the internalization of these value systems appears to shape universal emotions, traits and selfconceptions into culturally specific sentiments, motives and social selves.

\section{Therapeutic Action: Need for a Different Perspective}

The nature of psychotherapy in the region is an issue to be explored. It is directive, advisory, caring, and critical where a state of complete autonomy and individuation is not desirable. The therapist is expected to express more of his emotions. Models of therapy that do not provide for spiritual understanding or space for contextualizing cultural issues can be fraught with difficulties. That's why culture sensitive psychotherapy requires understanding and adaptation of religious principles as the core of the therapeutic relationship. The strategy is to deal primarily with conscious problems, symptoms, thoughts, feelings 
and memories. An important motivation in social interactions is to save face and avoid being shamed. Inner desires, wishes and conflicts that are socially unacceptable must be kept secret. Inner exploration may threaten the integrity of the psyche (26).

Schizophrenia as a mental illness has different connotations. Schizophrenia patients are held less responsible for their negative symptoms compared to West. Belief in fate decreases the tendency to blame patients for their symptoms. Catatonic forms of the disorder are relatively common compared with other varieties (27). Male schizophrenics living with the extended family in Qatar tended to have less chronic symptoms (28). Increased prevalence of catatonia may be due to a delay in help seeking, retardation might not be recognized as a mental illness. Most people attribute their disorder to the evil eye or jinn possession. Envy and evil eye are frequently reported as causes of mental illness. In Turkey, unrequited love, has been perceived as a cause, as in the case of Majnun. Unrequited love gives a very humane explanation to the bizarre behaviors of the schizophrenic and evokes sympathy towards his suffering. This helps him to be kept within the society and be respected for his grief. On the other hand, some changes are on the way, by the modernization process. Some very recent research indicates that the traditional views of schizophrenia change with modernization in Turkey. It is now regarded as a mental illness to be cured by psychiatrists rather than a state of jinn possession. But public still hold the social factors responsible for the etiology of schizophrenia and view help seeking from local healers as positive (29). Insanity is described by the aggressiveness, instability, and nonconformity and as the disorder is being labeled as a brain disorder the stigma attached to it becomes more prominent (28). Social distance studies in Turkey show that majority of the people do not want to live close by to a schizophrenic $(30,31)$. As we know, there is a more benign course of schizophrenia in the developing countries. Families give positive messages where there is less labeling. In Turkey, as the emphasis shifts towards the brain, calling schizophrenia a brain disorder, the stigma of the illness increases contrary to the expected situation.

Depression is also mostly associated with somatic symptoms in the Middle East (32). Depressive mood is part of the depression. Somatization does not exclude affect as a medium for expressing distress. Guilt feelings might be or not. Hamdi et al (18) support the view that guilt feelings are less readily elicited in Arabs and may require higher degrees of rapport between patient and clinician; guilt, as well as loss of libido, they argue, has minimal predictive value for the diagnosis of depression, because relevant questions in the traditional Islamic culture cause discomfort and are considered inappropriate. El-Islam, considers guilt a common phenomenon in Muslim groups $(33,34)$. It has been reported that non-Western cultures emphasize social integration rather than autonomy: Shame is more important than guilt. Also somatic manifestations of the psychological distress are more acceptable and likely to evoke a caring response than vague complaints of psychological symptoms (27). There are alternative explanations for psychological problems. Misery sometimes is expressed through reports of a fallen or painful heart, or as chest tightness or as distress of the heart. Alternative descriptions of unhappiness from other cultures are not conceptually inferior to the concept of depression as a Western medical representation. Sadness is valued as a sign of inner growth, which reminds the finitude of life, the fragility of existence. Sadness is also regarded as a means of sensitivity in Buddhism and Confucianism or as a sign of piousness in Islam where resilience and endurance is promoted $(17,35,36)$.

\section{Psyche and Art in the Middle East}

Human life is short through with unavoidable suffering, and that there are fixed limits to human happiness according to Eastern culture. Wisdom resides in understanding and accepting those limits. It is essential to try to improve oneself, by moral effort, as far as one's nature allows but it is foolish and dangerous to think that nature, or human nature, can be altogether overcome (35). A sense of the tragic in life is associated with depth of the inner self, as opposed to shallowness of the outer self. Also the ability to express sadness appropriately and in a culturally proscribed manner is a mark of social competence as well as personal depth in the region (17). Traditional Turkish poetry also values sadness. According to Traditional Turkish poetry, sadness is a core element in piety and a marker for sincerity towards God. Many poets praise sadness and find a virtue in it. Some poets treat 
sorrow and sadness as an honorable guest, who teaches much during his visit. This treatment is portrayed in the following poem of Rumi:

\section{GUEST HOUSE}

This being human is a guesthouse.

Every morning a new arrival.

A joy, a depression, meanness, some momentary awareness comes

as an unexpected visitor.

Welcome and entertain them all!

Even if they're a crowd of sorrows,

who violently sweep your house

empty of its furniture,

still, treat each guest honorably.

He may be clearing you out

for some new delight.

The dark thought, the shame, the malice, meet them at the door laughing,

and invite them in.

Be grateful for whoever comes, because each has been sent as a guide from beyond.

Not only poetry but also music played an important role in the rise of depression and value for sadness. This lead to confusion about sadness and depression. Nobel laureate Turkish novelist Orhan Pamuk talks about a collective melancholy, 'the black mood felt by millions of people together', and hüzün of the city of Istanbul. Hüzün engulfs the entire ancient city, imparting a particular coloring, mood and zeitgeist (38). 'Istanbul does not carry its hüzün, as an illness for which there is a cure or an unbidden pain from which we need to be delivered; it carries its hüzün by choice and with honor' $(38,39)$.

There are popular songs on the experience of depression that depression also narratives in the media by celebrities and films. By the time depression becomes a popular word and antidepressants are used as a nostrum. In Turkish version of depression, there are both pros and cons in the phenomenon. First of all, people consult to doctors for their depression more easily and there is more public awareness with media now. Somatic idioms of distress are slowly being replaced by psychological idioms. There is more willingness for selfdisclosure and depression is not so much romanticized. However there is still less emphasis on resilience. Though the religious tradition favors resilience over giving up, the modern project in its pursuit of an 'analgesic society' recommends a 'tranquility pill' for every ill. Emphasis is still on the psyche of the individual rather than the context. The buffering of social institutions has diminished where drugs are at times overprescribed. Mohammad Shafii writes about the Sufi way of handling stress: ' The Sufis, feel the psychic suffering and pain are essential throughout life. The goals of the Sufis are the vision of reality, union with the beloved, and integration of personality. This requires pain, suffering and sacrifice. Alleviation of symptoms and the development of health and well-being are not the goals but the side effects' (40). Sufism has also concentrated on humanity and psyche to depict the life and understanding of it. Hence, it teaches that "the heart" lies in the center of man's being; which is not only a flesh located at the chest; but also a divine and spiritual subtlety connected with the physical heart as the true essence of man (41).

\section{Predominant Psychiatric Symptoms in the Middle East}

On the other hand other psychological problems present with different symptoms. Dramatic forms of conversion disorder are still prevalent in the Middle East. Hysteria is mostly replaced by somatoform disorders in Turkey (42). Obsessive Compulsive Disorder has its own colorings in the Middle East. In the Egyptian context the most commonly occurring obsessions were religion and contamination (60\%) and somatic obsessions (49\%) (27). According to researches religious obsessions may be overrepresented in the clinical populations of Muslim and Jewish Middle western cultures $(43,44)$. This may be due to the emphasis on cleanliness and ritual purity, and where the sexual matters can be issues of prohibition, sin and shame $(43,44)$. Studies of Turkish patients with OCD indicated that religious obsessions are present $11-42 \%$ of patients, and its prevalence showed a tendency to increase 
eastward, reflecting the more conservative and more religious society in the East (45-48). There is also a possible influence of the concept of spiritual purity on OCD phenomenology (49). Patients' attitude toward their illness is also critical. Studies show that there is a delay in helpseeking. Suicide on the other hand is affected by the cultural influence. Intention of killing oneself is not common among Muslims, for whom losing hope from relief by God and self-inflicted death are blasphemous and punishable in the afterlife (27). Wish to die is not uncommon; it usually remains at the level of wishing that God would terminate their life, and does not progress to the wish to kill themselves (50).

\section{Biological Meaning versus Morality: Perspective on Psychopathology in the Middle East}

Western psychiatry avoids any religious or spiritual perspective or any framework for the meaningfulness of life where traditional and religious healers play a major role in primary psychiatric care in many Middle East countries. The extended families show high level of tolerance to assimilating family members with psychiatric illness. The social change coming with modernization may subject women to conflicting roles and may increase drug and alcohol abuse $(23,27,51)$. The impact of American Psychiatry is built upon the medicalization of human suffering, reification of illness categories and loss of local worlds of meaning.

In sum, the moral meaning of being ill is lost and biologic modeling of mental processes is more valued. This is what Ethan Watters (52) calls, 'the globalization of the American psyche': 'Western ideas of mind are proving as seductive to the rest of the world as fast food and pop music, as we are spreading them with speed and vigor'. And this ends in 'pathologization of everything' (53), which does not let us understand the hüzün, the peculiarly Turkish melancholic state surrounding the city of Istanbul, as Pamuk observes, 'feeling that the city of Istanbul carries as its fate'.

\section{References:}

1. Abi-Hashem N. (2006) The Agony, silent grief, and deep frustration of many communities in the middle east (In) Handbook of Multicultural Perspectives on Stress and Coping (eds. Wong P. \& Wong L.) Springer

2. Said E. (1978) Orientalism. Vintage Books.

3. Hentsch T. (1996) Imagining the Middle East. Black Rose Books.

4. Dols M. (1992) Majnoon, The Madman in Medival Islamic Society. Clarendon Press.

5. Songar A. (1974) Ilim-Kultur ve Sanatta Gercek, Istanbul, Vol.7, No: 3 P. 39-40

6. Shefer-Mossensohn M. (2009) Ottoman Medicine: Healing and Medical Institutions. State University of New York Press, Albany, New York.

7. Karam E.G, Howard D.B., Karam A.N., Ashkar A., Shaaya M., Melhem N., El-Khoury N. Major depression and external stressors: the Lebanon Wars. European Archives of Psychiatry Clinical Neuroscience 1998;248:225-30.

8. Karam E.G., Mneimneh Z.N., Karam A.N., Fayyad J.A., Nasser S.C., Chatterji S., Kessler R.C. Prevalence and treatment of mental disorders in Lebanon: a national epidemiological survey The Lancet 2006;367:1000-1006.

9. Al-Krenawi A., Graham J.R., Dean Y.Z., Eltaiba N. Cross-national study of attitudes towards seeking professional help: Jordan, United Arab Emirates (UAE) and Arabs in Israel. The International journal of social psychiatry 2004;50:102-14.

10. El-Sarraj I. (1991) The Palestinians: under occupation (In): Mental Health Services in the Global Village (eds L. Appleby \& R. Araya), 109-114. London: Gaskell.

11. Murad I. \& Gordon H. Psychiatry and the Palestinian population Psychiatric Bulletin 2002;26:28-30

12. Greene, R.A (2005). War takes toll on Iraqi mental health. 12 August. http://news.bbc.co.uk/2/hi/middle_east/4620279.stm

13. Al-Ashhab B. An update on mental health services in the West Bank. Israel Journal of Psychiatry 2005;42:81-83.

14. Ozturk, O. M. (1964) "Folk Treatment of Mental Illness in Turkey." (In) Magic, Faith, and Healing, Ari Kiev, editor, New York: The Free Press.

15. Elliott C. (2003) Better Than Well: American Medicine Meets the American Dream. WW Norton Press.

16. Shoaib K. \& Peel J. Kashmiri women's perceptions of their emotional and psychological needs, and access to counselling. Counselling and Psychotherapy Research 2003;3:87-94.

17. Good M.J., Good B.J., Moradi R. (1984) The Interpretation of Iranian Depressive Illness and Dysphoric Affect (In) Culture and Depression (eds. Kleinman A. \& Good B.) University of California Press

18. Hamdi E., Yousreya A. \& Abou-Saleh M. T. Problems in validating endogenous depression in the Arab culture by contemporary diagnostic criteria. Journal of Affective Disorders 1997;44:131-143. 
19. Sulaiman S., Bhugra D. \& De Silva P. Perception of depression in a community sample in Dubai. Transcultural Psychiatry 2001;38:201-218.

20. Mirdal, G.M. The condition of 'tightness' : the somatic complaints of Turkish migrant women. Acta Psychiatrica Scandinavica 1985;71:287-296.

21. Baarnhielm S. \& Ekblad S. Turkish migrant women encountering health care in Stockholm: A qualitative study of somatization and illness meaning. Culture, Medicine, and Psychiatry 2000;24:431452 .

22. Mac Phee M.J. Medicine for the Heart: The Embodiment of Faith in Morocco. Medical Anthropology 2003;22:53-83.

23. Bhugra D. (1996) Psychiatry and Religion: Context, Consensus and Controversies. Routledge Press.

24. Kirmayer, L.J. \& Young A. Culture and Somatization: Clinical, Epidemiological, and Ethnographic Perspectives. Psychosomatic Medicine 1998;60:420-430.

25. Bhugra D. \& Mastogianni, A. Globalisation and mental disorders. The British Journal of Psychiatry 2004;184:10-20.

26. El Leithy W. (2000) Arab psychotherapy (In) Images in Psychiatry: An Arab Perspective (eds A. Okasha \& M. Maj), pp. 247-254. World Psychiatric Association.

27. Okasha, A. Focus on psychiatry in Egypt. British Journal of Psychiatry 2004;185:266-272.

28. El-Islam M.F. A better outlook for schizophrenics living in extended families. British Journal of Psychiatry 1979;135:343.

29. Taşkın E.O., Sen F.S., Aydemir O., Demet M.M., Ozmen E., Icelli I. Public attitudes to schizophrenia in rural Turkey. Turkish Journal of Psychiatry 2003;15:47-55.

30. Sağduyu A. An Epidemiologic Investigation of the Public's Attitudes Towards Schizophrenia. Turkish Journal of Psychiatry 2001;12:99-110.

31. Sağduyu A. Relatives beliefs and attitudes toward schizophrenia: an epidemiological investigation. Turkish Journal of Psychiatry 2003;14:203-12.

32. Sayar K., Kirmayer, L.J. Taillefer, S. Somatic Symptom Reporting in Depressed Outpatients. General Hospital Psychiatry 2003;25:108114.

33. El-Islam F. M. Depression and guilt: study at an Arab psychiatric clinic. Social Psychiatry 1969;4:56-58.

34. El-Islam M.F., Moussa M.A., Malasi T.H., Suleiman M.A., Mirza I.A. Assessment of depression in Kuwait by principal component analysis. Journal of Affective Disorders 1988;14:109-114.

35. Kirmayer, L.J. Psychopharmacology in a globalizing world: The use of antidepressants in Japan. Transcultural Psychiatry 2002;39:295312 .
36. Lock, M. (1993) Knowledge, Power and Practice: The Anthropology of Medicine and Everyday Life, edited with Shirley Lindenbaum. Berkeley: University of California Press.

37. Barks C. (1995) The Essential Rumi. Harper Collins.

38. Bowring J. (2008) A Field Guide to Melancholy. Oldcastle Books, UK.

39. Pamuk, O. (2005) Istanbul: Memoirs of a city. Vintage Publishing.

40. Shafii M. (2008) Sufi Perspective on Human Suffering and its Relief (In) The Crescent and the Couch ( ed Salman Akhtar), Jason Aronson, NY.

41. Sviri S. (2002) The Taste of Hidden Things. Golden Sufi Center, California.

42. Sayar K. \& Isik H. (2006) Somatoform Disorders (In) Guncel Klinik Psikiyatri. Golden Print Press, Ankara, 269-289.

43. Maghoub, O.M. \& Abdel Hafeiz H.B. Pattern of obsessivecompulsive disorder in eastern Saudi Arabia. The British Journal of Psychiatry 1991;158:840-2.

44. Shooka A., Al- Haddad M.K., Raessa A. OCD in Bahrain: a phenomenological profile. International Journal of Social Psychiatry 1998;44:147-54.

45. Egrilmez A., Gulseren L., Gulseren S., Kultur S. Phenomenology of obsessions in a Turkish Series of OCD Patients. Psychopathology 1997;30:106-110.

46. Tezcan, E. \& Millet, B. Obsessive-compulsive disorder phenomenology: Forms and Contents of obsessions and compulsions in East Turkey. L’ Encéphale 1997;23:342-50.

47. Tek C. \& Ulug B. Religiosity and religious obsessions in obsessivecompulsive disorder. Psychiatry Research 2001;104:99-108.

48. Karadag F., Oguzhanoglu N.K., Ozdel O., Atesci F.C., Amuk T. OCD symptoms in a sample of Turkish patients: a phenomenological picture. Depression and Anxiety 2006;23:145-52.

49. Ghassemzadeh $\mathrm{H}$, Mojtabai R, Khamseh A, Ebrahimkhani N, Issazadegan AA, Saif-Nobakht Z. Symptoms of obsessivecompulsive disorder in a sample of Iranian patients. International Journal of Social Psychiatry 2000;48:20-28.

50. El-Islam M.F. (2000) Social psychiatry and the impact of religion. (In) Images in Psychiatry: An Arab Perspective ( eds A. Okasha \& M. Maj), pp. 21 -36. World Psychiatric Association.

51. Gordon H. \& Murad I. Psychiatry and the Palestinian population. The Israel Journal of Psychiatry and Related Sciences 2005;42:7380 .

52. Watters E. (2010) Crazy Like Us: The Globalization of the American psyche. Free Press, NY.

53. Conrad P. (2007) The Medicalization of Society. Johns Hopkins University Press. 